\title{
Article \\ An Assessment of Regional Sustainability via the Maturity Level of Entrepreneurial Ecosystems
}

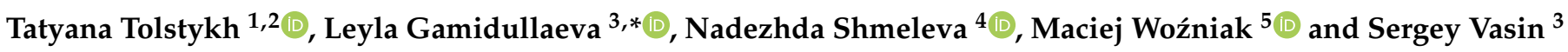 \\ 1 Department of Industrial Management, National University of Science \& Technology (MISIS), \\ 119049 Moscow, Russia; tt400@mail.ru \\ 2 Department of the Digital Economy and Information Technologies, Plekhanov Russian University of \\ Economics, 119049 Moscow, Russia \\ 3 Department of Economics and Management, Penza State University, 440026 Penza, Russia; pspu-met@mail.ru \\ 4 Department of Economics, National University of Science \& Technology (MISIS), 119049 Moscow, Russia; \\ nshmeleva@misis.ru \\ 5 Department of Economics, Finance and Environmental Management, Faculty of Management, \\ AGH University of Science and Technology, 30-067 Cracow, Poland; mwozniak@zarz.agh.edu.pl \\ * Correspondence: gamidullaeva@gmail.com; Tel.: +7-909-317-3366
}

Citation: Tolstykh, T.; Gamidullaeva, L.; Shmeleva, N.; Woźniak, M.; Vasin, S. An Assessment of Regional Sustainability via the Maturity Level of Entrepreneurial Ecosystems. J. Open Innov. Technol. Mark. Complex. 2021, 7, 5. https://doi.org/10.3390/ joitmc7010005

Received: 30 November 2020 Accepted: 19 December 2020 Published: 25 December 2020

Publisher's Note: MDPI stays neutral with regard to jurisdictional claims in published maps and institutional affiliations.

Copyright: (c) 2020 by the authors. Licensee MDPI, Basel, Switzerland. This article is an open access article distributed under the terms and conditions of the Creative Commons Attribution (CC BY) license (https: / / creativecommons.org/ licenses/by/4.0/).
Abstract: Despite the prominence of sustainable development approaches in the academic literature, together with the significance attributed to the economy and society, the concept is not sufficiently theorized, especially in terms of methodological issues. The presented study makes a contribution to the academic literature by providing a synthesis on territorial sustainable development research and related concepts of innovation and entrepreneurial ecosystems (EE). We propose a methodological framework for the assessment of regional sustainability, replicating and expanding the approach of D. Isenberg, and draw inference to the impact of institutional environments on the maturity level of EEs. We present our assumptions in the example of two entrepreneurial ecosystems in Russia and Poland (the Penza region and the Małopolska region) with relevant interpretations, which enable us to gain a comprehensive understanding of how to progress in sustainable entrepreneurial ecosystem development. The results of this analysis provides information to help academics, policymakers, government, and business owners with a more in-depth understanding of the practical mechanisms that support absorption of the EE model to achieve Sustainable Development Goals.

Keywords: innovation ecosystem; sustainable development; region; territory; open innovation; ecosystem maturity; entrepreneurial ecosystems

\section{Introduction}

Technological and environmental challenges confront the society with the need to change traditional approaches and principles of management at the regional and municipal levels. Back in 1992, a sustainable development strategy was adopted at the United Nations (UN) World Conference, and in 2015, 17 Sustainable Development Goals (SDGs) until 2030 were formulated. The key areas of sustainable development are ecology, technology, and quality of life. These strategic directions predetermine the search for management tools and mechanisms for their achievement at the level of regions and states in the face of constant political, technological, and environmental challenges. The importance of the social aspect of sustainability in the development strategy of enterprises has been particularly aggravated by the situation with the pandemic. Many enterprises have been forced to restructure their target vectors of development, taking into account the safety of both their employees and the workers of partner organizations as well as clients.

The study of sustainable development from a regional point of view is of particular importance. Regional sustainable development assumes that the population of a particular region can achieve an acceptable level of well-being, both now and in the long 
term perspective, and that such regional development is compatible with environmental conditions in the long term, which ultimately allows achieving global sustainable development [1]. Consequently, regional sustainable development is focused on achieving the following goals: first, to ensure a sufficient level of quality of life for the regional population; secondly, it should correlate with sustainable development goals at the supra-regional (national and global) level [2]. It follows from this that the UN SDGs should be projected at the regional level.

It is clear that specific regions can have significant distinctive characteristics due to regional differences (for example, natural resources presence and utilization and human capital, environmental aspects, and the socio-economic distribution of income and employment).

Therefore, if all regions pursue the same SDGs, then the development of the entire global system will also be sustainable. Furthermore, every region should have its own development strategy, as a rule, corresponding to a common understanding of sustainable development, formulated by the UN World Conference and reflected in 17 Sustainable Development Goals.

Regional sustainable development involves a meso-level analysis. However, it is extremely difficult to draw a clear demarcation line, define the boundaries, and fix the spatial dimension of the region. In this regard, the ecosystem view on regional sustainable development helps, firstly, to integrate research approaches to sustainability at various levels of integration (macro, meso, and micro). Secondly, to combine the fundamental approaches of the complexity theory (synergetics), the sustainable development concept, spatial and regional studies, institutional approach, with the aim to form a holistic vision and an integrated approach to solving sustainable development problems from a multidisciplinary perspective.

The ecosystem consists of a dynamic interactive network with participants featured by innovative thinking focused on the creation and dissemination of knowledge. They may be virtual and platform-based as a result of digital transformation processes, however, the aspect of embeddedness in a specific territorial context (regional, local) is considerably important, since participants need to interact and create together, and to generate innovations using their multidisciplinary skills, abilities, and competencies [3].

This approach will bring organizations closer together and improve the efficiency of developing sustainable and knowledge-intensive products through co-creation, leveraging institutional integration, and improving the distribution of knowledge and assets within the ecosystem [4]. As a consequence, firms need to move away from an organizationcentered innovation strategy and develop co-creation and co-development together with developing ecosystem thinking [3].

The ecosystem model makes it possible to form a friendly environment, ensuring the implementation of the principles of sustainable development where the goals of all stakeholders are harmonized and a rigid vertical management is absent. An ecosystem effect occurs when technology stimulates the transfer of knowledge in the regional innovation environment, as well as leading to increased productivity within the company, in the supply chain and within cross-industrial sectors. Moreover, it contributes to the sustainable development of each of the ecosystem players and the region as a whole.

Obviously, the SDGs at the macro-level can be more easily achieved if the process of socio-economic development and environmental change at the regional level is clearly understood and managed. To develop specific management mechanisms, adequate approaches to assessing the current level of sustainable development of the region are required.

In the previous articles [5-9], the authors have investigated the sustainability of regional development from the perspective of the balance of three capacities: socio-economic, technological, and environmental. Continuing the study in the same aspect, we believe that the most significant reasons that impede the implementation of strategic directions aimed at sustainable development of the region are as follows: 
$>$ imbalance and inconsistency of targets of the structures that make up the regional system;

$>$ lack of motivation in search for collaborative relationships;

$>$ prevalence of short-term goals over strategic goals;

$>$ prevalence of solutions of economic problems over social and environmental issues.

Therefore, the objective of this study is to assess the sustainability of the regional development via the prism of ecosystem model.

An assessment and analysis of sustainable development of the region should provide an opportunity to develop operational guidelines and an algorithm of specific actions aimed at achieving SDGs.

The presented paper contributes to the academic literature by providing a synthesis on territorial sustainable development research and related concepts of innovation and entrepreneurial ecosystems. Moreover, it proposes a framework for the assessment of regional sustainability, replicating and expanding the approach of D. Isenberg [10]. In addition, it enhances the existing literature in the field of New Institutional Economies [11] as the paper draws inference to the impact of institutional environments on the configuration and practices of EEs through the application of institutional theoretical perspectives. Therefore, the paper proposes an approach to the analysis of territorial sustainable development in the context of regional specificities via assessing the level of entrepreneurial ecosystem maturity in Russia and Poland (the Penza region and the Małopolska region).

The article is organized as follows. First, regarding a theoretical overview of the entrepreneurial ecosystems, related schools of thought are provided. The research hypothesis is also elaborated. Section 3 introduces the methodology, followed by Section 4, which presents our assumptions with an empirical case study provided in Russia and Poland (the Penza region and the Małopolska region). In Section 5, the authors make some concluding remarks and discuss propositions arising from the conducted analysis and their implications in terms of further regional sustainable development. The key findings of the study, theoretical contribution and practical significance of the study are highlighted. In Section 6, the constraints of the research and pathways for further research are suggested.

\section{Literature Review}

In the era of digitalization, the innovative aspect in the sustainable development of enterprises is gaining great importance, which creates the main challenge for organizations. With the active creation of collaborations and networks, the rapid development of the open innovation paradigm began to have a strong impact on the enterprises. Sustainable development requires resources and capabilities, as well as the implementation of sustainable innovations. Sustainable innovation differs from conventional innovation in new features that are associated with desirable market attributes such as longevity, resource efficiency, locality, and reduced environmental load [3]. The implementation of sustainable innovations alone becomes almost impossible in modern conditions, given the flexible demands of the environment. Thus, collaboration via open innovation platforms becomes a crucial factor to ensure entrepreneurial sustainable development [8].

Innovative sustainable development assumes the creation of favorable environments for all stakeholders. With the development of a collaborative approach to innovation, termed "open innovation", the owners and managers of enterprises are focused primarily on obtaining the final product, regardless of the place of creation of a new result and the origin of the resources necessary for its creation. In these conditions, the boundaries of the organization become more flexible, a dynamic symbiotic process of combining internal and external knowledge, resources, as well as all stakeholders is being formed. Organizations are becoming part of a wider environment of interactions with the environment and various stakeholders.

Meanwhile, within the framework of "open innovation", the big companies, which shape innovative markets and value networks for their innovations, are dominated. Small and medium-sized companies (SMEs), including start-ups, face financial and human 
resource constraints. Therefore, they are focused on a shorter time horizon. Moreover, SMEs have to tackle difficulties in implementing innovative strategies. They have to choose whether to allocate funds for attracting highly qualified personnel as well as initiating and implementing projects, or to depend on external sources of information, knowledge, competencies, and technologies. Therefore, special external support is required mainly in the case of SMEs. This can be in the form of partnerships, the creation of cluster initiatives, which will ensure a quick response to market changes in the form of sustainable innovations.

That is why, in the past few years, the scientific community has been actively studying and discussing the innovation ecosystem as a new model of interaction between enterprises [4-10].

There are many concepts of an ecosystem, but the authors suggest it is fundamental to consider the ecosystem via the synergetic association of the main components: actors, connections between them, the environment formed as a result of interactions, a unifying idea (pacemaker), and an exchange of energy in the form of knowledge, information, and competencies. The development of sustainable ecosystems is a collaborative creative process in which every actor mutually benefits from a set of different skills, abilities and knowledge that will complement each other (Figure 1).

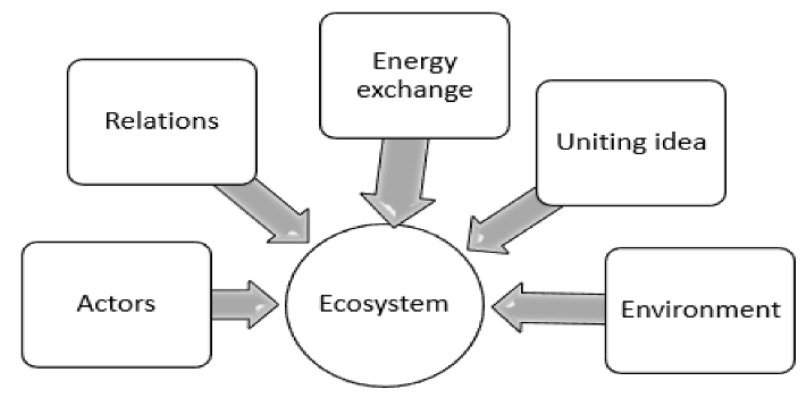

Figure 1. Main components of an ecosystem.

The authors consider self-organization and self-development of actors, networking, and collaboration based on trust, partnership, mutual exchange of resources, and project orientation to be the basic principles for the formation of ecosystems.

A region is the intersection and unification of many ecosystems, allowing each participant to contribute to creating an environment for their effective development. Ecosystems studied in the literature are usually divided into territorial (regional/local), entrepreneurial, innovation, sectoral, social, or educational. However, entrepreneurial ecosystems are the most important subject of debate. As far as innovation ecosystems are regarded, according to P. Drucker [12], innovation activity is a special type of entrepreneurship, therefore, entrepreneurial and innovation ecosystems can be considered as a single whole. If we consider sectoral ecosystems, entrepreneurship and innovations are undoubtedly the drivers for the development of any industry. In addition, the modern trend of educational systems is the transformation of traditional educational and research universities into the model of entrepreneurial universities. That is, each forming or already formed ecosystem can be represented as a kind of entrepreneurial ecosystem.

Over the years, entrepreneurship has often been positioned as an effective mechanism for increasing the economic performance of a territory, as one of the main factors determining its economic results [13]. Scientists rightly state that innovation and entrepreneurship can complement each other and, collectively, act as a powerful source of productivity and competitiveness, reducing poverty and stimulating long-term economic growth [14-16]. The concepts of "innovation ecosystem" and "entrepreneurial ecosystem" are quite often used as synonyms. Some researchers argue that the first concept is broader than the latter, since it implies development along with the innovative entrepreneurship and traditional businesses, for example, social, environmental or youth, which also require certain conditions for effective development [17]. Scientists also use the concept of innova- 
tion and entrepreneurial ecosystems and consider them as a factor of regional sustainable development [18].

The concept of entrepreneurial ecosystems is associated today with complexity and diversity [19], interaction networks [20-23], a multidimensional set of interacting factors [24], a group of participants [25], or a dynamic community [26]. Many scientists consider entrepreneurial ecosystems as networks of interaction of business agents of various specializations, acting in a certain geographically limited natural, economic, institutional, and other conditions [20-23].

Other definitions of entrepreneurial ecosystems are focused on the creation of new entrepreneurial opportunities and describe them as those economic, social, institutional, and other key aspects that interactively affect the creation, discovery, and use of entrepreneurial opportunities [27].

Bruns and co-authors consider entrepreneurial ecosystems as a multidimensional set of interacting factors that collectively affect certain social or economic indicators, for example, mitigating the impact of entrepreneurial activity on economic growth [24].

Territorial aspect is differently understood in relation to entrepreneurial ecosystem concept. There is a general agreement that the entrepreneurship grows in local/regional ecosystems. Some scholars position territorial specificity as one of the aspects of the concept [28], others as a tool for regional and local development [29]. In addition, the researchers differentiate regions into those with a "healthy" entrepreneurial ecosystem, which have a greater ability to materialize the effects of high rates of business creation, regardless of their quality, and the regions with a "weak" entrepreneurial ecosystem, which can rely on innovative entrepreneurs to compensate for the lack of policies to support entrepreneurship and improve their economic performance [13].

Spigel believes that ecosystems consist of 10 cultural, social, and material attributes that provide benefits and resources to entrepreneurs, and that the relationships between these attributes reproduce the ecosystem itself [29].

According to Audretsch and Belitski, a dynamic community of interdependent entrepreneurial ecosystem actors includes, among others, entrepreneurs, suppliers, buyers, and governments [24]. Some researchers highlight the role of public policy in the development of entrepreneurial ecosystems, and testifies to the influence of the government both on entrepreneurs themselves and people with entrepreneurial abilities (potential entrepreneurs), on stimulating their initiative. Scientists have also identified the impact of state institutions with regulatory frameworks on the performance of various types of entrepreneurship as well as government measures to encourage entrepreneurial initiatives and support the entrepreneurial community $[30,31]$.

Different views of scientists on the definition of the concept of EE and its structure also determine the originality in substantiating the very concept of EE or the principles of its functioning and development. One of the concepts related to EE is the entrepreneurship absorptive capacity theory, which defines new knowledge as one of the sources of entrepreneurial opportunities, and founds human capital as the most important source of entrepreneurial absorptive capacity. Based on the results of studies of this theory, scientists conclude that the entrepreneurial ability of absorption is the most important driver of knowledge-based entrepreneurship. Furthermore, high technology and cultural diversity rightfully contribute to the viability of regional entrepreneurship systems [29].

Scientists also discuss the intense high-tech entrepreneurship fostering EE development [32]. Cohen verifies how the elements of both formal and informal networks, physical infrastructure, and culture within a community contribute to the creation of a sustainable entrepreneurial ecosystem [25].

The authors [31] provide a holistic and dynamic approach concerning value creation, entrepreneurial activity EE elements and relational interactions within institutional environments. According to Spigel, the combination of social, political, economic, and cultural elements in the region that support the development and growth of innovative start-ups encourages emerging entrepreneurs and other EE participants to take risks [29]. 
Other scholars propose a comprehensive startup model, and a regional entrepreneurship and development index within regional EEs [26].

In terms of territorial perspective, it is suggested that the local entrepreneurial ecosystem is part of a larger regional, national, international, and even global ecosystem. Although all economic activity is ultimately local, there is no reason to assume that the most significant boundaries of the ecosystem coincide with any administrative-geographical units [24]. Table 1 provides a conceptual overview of approaches to entrepreneurial ecosystems (see Table 1).

Table 1. Content analysis of entrepreneurial ecosystem definitions.

\begin{tabular}{|c|c|}
\hline An Entrepreneurial Ecosystem Concept & Authors \\
\hline $\begin{array}{l}\text { An entrepreneurial ecosystem is a set of interacting entrepreneurs } \\
\text { (both existing and potential), organizations (major firms, venture } \\
\text { capitalists, business angels, banks), institutions (universities, } \\
\text { public organizations) that formally or informally are united to } \\
\text { cooperate and manage performance in local business environment. }\end{array}$ & $\begin{array}{l}\text { Mason, K., Brown, R., Greve, A., Salaff, J.W., Brundin, E., } \\
\text { Schilling, M.A., Phelps C.C., et al [33-37] }\end{array}$ \\
\hline $\begin{array}{l}\text { An entrepreneurial ecosystem is a system of interconnected } \\
\text { components that determine opportunities and pace for creating and } \\
\text { scaling new sustainable businesses by entrepreneurs. }\end{array}$ & D. Isenberg $[38,39]$ \\
\hline $\begin{array}{l}\text { An entrepreneurial ecosystem should be considered in terms of three } \\
\text { main characteristics: availability of opportunities, experienced } \\
\text { people, and resources. These characteristics can be summarized in the } \\
\text { form of six key factors: normative legal regulation; market conditions; } \\
\text { access to financing; research and developments; entrepreneurial } \\
\text { opportunities; culture. }\end{array}$ & $\begin{array}{l}\text { The Organisation for Economic Co-operation and } \\
\text { Development (OECD) [40-42] }\end{array}$ \\
\hline $\begin{array}{l}\text { A set of interconnected business structures and organizations (firms, } \\
\text { venture capital companies, investors-sponsors, banks), institutions } \\
\text { (universities, government organizations, financial institutions), } \\
\text { as well as business practices (creation of commercial enterprises, } \\
\text { growth, extra-large transactions, number of serial entrepreneurs, } \\
\text { willingness to sell their company, the level of entrepreneurial } \\
\text { ambitions), which together provide not only the presence of } \\
\text { connections and an intermediary environment, but also allow to } \\
\text { manage the efficiency of local business environments. }\end{array}$ & $\begin{array}{l}\text { The concept developed by OC\&C to assess tech } \\
\text { entrepreneurship success [43] }\end{array}$ \\
\hline $\begin{array}{l}\text { An entrepreneurial ecosystem is a network of interaction between } \\
\text { business agents of various specializations, formed under certain } \\
\text { territorially limited natural, economic, institutional, } \\
\text { and other conditions. }\end{array}$ & $\begin{array}{l}\text { Audretsch, D., Baburin V.L., O'Connor, A., Sternberg, R., } \\
\text { Sussan, F., Wagner, J., Stam, E. Zemtsov S.P. [20-22,28] }\end{array}$ \\
\hline
\end{tabular}

Nowadays, approaches to the assessment of entrepreneurial ecosystems are widely presented in the academic literature and reports of international organizations. The starting point here is to identify the elements composing entrepreneurial ecosystems.

According to Feld [44], the main attributes of a successful start-up community are as follows: leadership, intermediaries, network density, government, talent, support services, engagement, companies, and capital. As proposed by the World Economic Forum, the entrepreneurial ecosystem pillars include accessible markets, human capital/workforce, funding and finance, support systems/mentors, regulatory framework and infrastructure, education and training, major universities as catalysts and cultural support [45]. Spigel [29] assumes that the attributes of entrepreneurial ecosystems include cultural (cultural attitudes, histories of entrepreneurship), social (networks, investment capital, mentors and dealmakers, worker talent) and material (universities, support services and physical infrastructure, policies and governance, strong local markets) elements [31].

The Kauffman Foundation Report (2015) [43] offers four integral indicators for assessing an entrepreneurial ecosystem: density, fluidity, connectivity, and diversity. In his works, D. Isenberg $[38,39]$ emphasizes that to build an effective entrepreneurial ecosystem, 
it is necessary to understand and integrate the development of all the elements of the entrepreneurial ecosystem. He identifies six domains of the entrepreneurship ecosystem: a conducive culture, availability of appropriate finance, quality of human capital, venture friendly markets for products, and a range of institutional supports. He gives an example that financing without education and culture will not lead to entrepreneurship. All these elements and their mutual influence on each other must be taken into account [46]. Ideas of Isenberg were further developed by M. Stam [22]. He revealed the systemic entrepreneurial ecosystem elements (networks, leadership, finance, talent, knowledge, and support services) as well as framework conditions (formal institutions, culture, physical infrastructure, and demand).

Studies of researchers from Aspen Network of Development Entrepreneurs [47], Organization for Economic Co-operation and Development, an international consulting firm OC\&C Strategy Consultants [48], Stanford University and Ernst \& Young Global Limited [49] have greatly contributed to the development of tools for assessing the level of development of entrepreneurial ecosystems.

After the analysis of various approaches to assessing entrepreneurial ecosystems, one can agree with J. Trabskaja and T. Mets [50], who believe that the models discussed in the academic literature are usually focused on regional (or national) entrepreneurial ecosystems. However, the global context is not the main subject of debate. When only considering entrepreneurial ecosystems from the level of some abstract unified model without taking into account the positioning of the country, region, or industry in which it is formed, the systemic vision is lost. R. Smilor and G. Kozmetsky [51] emphasized the importance of regional ecosystems, which make it possible to solve problems on the basis of an integrated, holistic, and flexible approach, taking into account political, socio-economic, cultural, technological, and managerial aspects in the context of ongoing changes and a limited time framework. The specifics and characteristics of the development of EE in countries with transition economies, most of which are classified by scientists as "weak ecosystems" [52], remains rarely studied by scientists.

As rightly noted in [33], there is much attention given to the concept of entrepreneurial ecosystems in the academic literature. There are many shortcomings connected with the concept. For example, it remains undisclosed what institutions impact on the structure and performance of EE. In addition, the authors [33] argue that current studies have often focused on the EE in single regions or clusters, but there is a dearth of a comparative and multi-scalar perspective.

In the study, the following hypothesis was set: there is a direct link between the level of regional sustainable development and the maturity of its entrepreneurial ecosystem.

Sustainable regional development should support the maintenance of a certain level of life through the effective use of economic, social, and environmental components on a particular region [6]. Effective integration of these three dimensions requires the implementation of a set of specific actions, which are fitted into a framework of sustainable development.

The problem of sustainable development is clearly detectable in the academic literature. There is a weak methodological elaboration of this theory, which challenges its practical implementation. The need to transfer the concept of sustainable development to the regional level is of great importance; however, in practice the use of this approach is fraught with a number of difficulties [53]. They are connected with monitoring the dynamics of sustainable development of the territory and approaches to its interpretation.

Social life-cycle assessment (S-LCA) is a tool for collecting, analyzing and disseminating information about social conditions and social factors related to production and consumption [54]. In fact, this approach is complementary to the sustainable development approach, with its main focus on the social aspects of sustainability and ensuring the local well-being. S-LCA allows us to assess the level of sustainable development of organizations, while social assessment criteria are developed separately from the environmental. 
Thus, the S-LCA approach provides significant support in decision-making aimed at achieving sustainable development goals as the most important factor affecting the enterprise's competitive position in the market.

This approach can serve as the basis for integrating the principles of sustainable development (mainly the social component) into the process of making sustainable management decisions in an organization.

To analyze and assess the level of sustainable development of regional ecosystems it is necessary first to understand that each country has its own institutional and cultural characteristics that directly influence the process of ecosystem formation.

\section{Methodological Framework}

Many researchers pay attention to the significant role played by common institutions and policies in affecting the economic results of a firm. Different business environments may have differential impacts when we consider the changing incentives for entrepreneurship. The classification of institutions by North [12] suggest that formal institutions relate to legislative rules and formal structures, whereas informal institutions refer to a specific values of community, beliefs and culture. Formal institutions are based on statutory restrictions, involving benefits and preferences for companies. For instance, these are specialized institutions that focus on the protection of intellectual property. Accordingly, informal institutions historically established are rooted in the minds and behavior of people through various ideas, norms, values, beliefs, patterns, or rules that are not formally fixed, but indirectly determine the nature and methods of relationships in the innovation system [55]. These institutions, for instance, showcase entrepreneurial culture, trust, and social capital, and are very important in making decisions. The improvement in the institutional environment and the increased certainty about the future have an impact on entrepreneurial behavior [55]. Formal and informal institutions constitute the "rules of the game" in a community and have an impact on the creation and the development of new ventures; this institutional framework influences the decision to become an entrepreneur and related entrepreneurial activities [56].

Using this concept in relation to assessing sustainable regional development, and to ecosystems, the following aspects can be emphasized:

1. Each region has its own "rules of the game"; therefore, when assessing ecosystems, one cannot ignore the specifics of the region from the perspective of the global level.

2. In the formation of entrepreneurial ecosystems, there is a prerequisite for institutions to understand such essential principles of ecosystems as self-organization and selfdevelopment. That means, the institutional "rules of the game" should allow and motivate the independence of management decisions for each actor, minimizing dictates from above. At the same time, the formal institutions act as participants in ecosystems on the principles of trust and partnership.

3. The formation and sustainability of regional ecosystems depends on both formal and informal institutions, and this process is mutual. Mature sustainable ecosystems make significant changes to the informal institutions from an evolutionary perspective.

It is advisable to analyze and assess ecosystems from the bottom-up and top-down perspectives at different stages of ecosystem maturity (Figure 2). At the initial stage of formation, only a micro-level is possible, which provides an opportunity to assess the potentials of specific participants, their possibilities, and the level of entrepreneurial culture. If the ecosystem has already been formed, then the assessment should start from the topfrom the global level going down to assessing the sustainable development of each actor, and then again going up the levels to adopt stratagems at each level of assessment. 


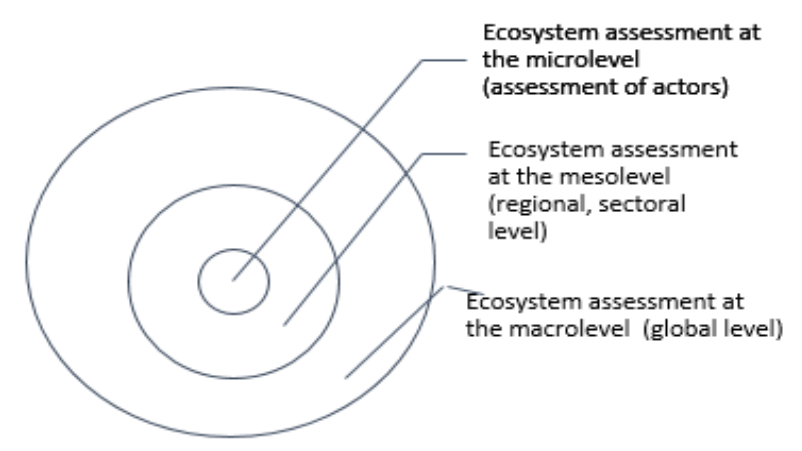

Figure 2. Approaches to assessing entrepreneurial ecosystems. Source: Own elaboration.

We define the maturity of ecosystems as the quality of the entrepreneurial processes in the society. D. Isenberg [36] recommends evaluating the assessment of the ecosystem maturity in four positions:

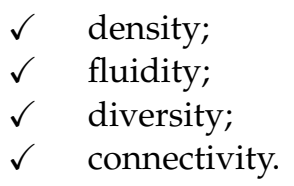

Each of these positions can be expressed in quantitative indicators. For instance, the ratio of the number of new and young firms to the population (labor force) and the share of these firms in employment can be used to estimate the density [57]. The fluidity can be measured through the dynamics of entrepreneurial activity, labor market mobility and the share of fast-growing firms. Diversity can be measured through the level of diversification of industries, and the share of technologically complex industries. And connectivity can be determined through the number of firms involved in the activities of support organizations [58], and the number of formed "spin off companies".

It is difficult to assess such characteristics of ecosystems as the level of entrepreneurial or corporate culture, and the level of motivation of entrepreneurial activity only by quantitative indicators, which, as a rule, is a consequence of informal institutions. Therefore, qualitative indicators are also needed for a systematic assessment of ecosystem maturity. One of such approaches in using both quantitative and qualitative indicators is the Global Entrepreneurship Monitor (GEM) project [52], where the indicators of "Perceptions of the quality of the business environment", evaluated by the expert method using a one (highly unsatisfactory) to nine (highly satisfactory) Likert scale according to the components of the conditions for the development of entrepreneurship, are as follows:

$>$ financing of entrepreneurship;

$>$ state policy;

$>$ state programs in the field of entrepreneurship;

$>$ entrepreneurial education;

$>$ introduction of scientific and technical developments;

$>$ commercial and legal infrastructure;

$>$ market openness;

$>$ physical infrastructure;

$>$ cultural and social norms.

In this study, we have selected the following quantitative and qualitative indicators as ecosystem components to assess entrepreneurial ecosystems based on the approaches of $\mathrm{D}$. Isenberg and OC\&C:

$\checkmark$ legislation (policy);

$\checkmark \quad$ level of motivation for entrepreneurial activity;

$\checkmark$ entrepreneurial recycling;

$\checkmark$ information accessibility;

$\checkmark$ entrepreneurial culture and education; 
$\checkmark$ human capital;

$\checkmark \quad$ financial infrastructure (availability of business angels, venture funds, business accelerators, etc.);

$\checkmark \quad$ IT infrastructure and communication technologies;

$\checkmark \quad$ market potential of the region.

As a result of the study, it was found that the concept of entrepreneurial ecosystems is not formalized enough, especially from the methodological point of view. Many works provide a list of indicators without any clear reasoning of causes and effects. Insufficient attention is paid to the study of the entrepreneurial environment in which an interaction between the actors takes place. Ignoring institutional factors can lead to mistakes in decisionmaking. To build effective models for managing the development of entrepreneurship at the regional level, a new approach is needed to study the features of the development of entrepreneurial ecosystems, which should be based on institutional and social aspects.

The authors have selected two countries for the analysis of ecosystems, namely Russia and Poland, belonging to the same geographic region (Europe), but with different income levels, average and high, respectively. In our opinion, it is this approach that is interesting in terms of comparing formal and informal institutions. For example, an assessment of the perception of market opportunities and the perception of the ease of starting a business can be called one of the most important factors in the maturity of an ecosystem. According to this indicator, Russia consistently occupies one of the lowest places among all the countries of the GEM project, and in Poland, this indicator is 50\% along with such countries as the USA, Great Britain and Canada. In 2018, according to the monitoring of the GEM project, $68 \%$ of Russians agreed with the statements about the high status of entrepreneurs in society, and that entrepreneurship is a good career choice. In Poland, this indicator was $85.9 \%$. But despite the comparative geographical proximity of the countries and the similarity of informal institutions in some positions, the countries differ significantly. For example, Russia belongs to the group of countries with a high prevalence of the idea of equality in living standards (more than $70 \%$ of society), while in Poland fewer than half of the respondents gave a positive answer to the question about the preference of uniform living standards. Although, in terms of entrepreneurial intentions, which is the readiness of an individual to create his own business, the percentage ratio of these two countries is comparable (5\% in Russia and $10 \%$ in Poland). The total early-stage entrepreneurial activity (TEA) indexes are also comparable (5\% in Poland and $6 \%$ in Russia), which can be explained by the similarity of regional features. But at the same time, the ratio of established and early-stage entrepreneurs in Poland is twice as high as in Russia. The ratios of Poland and Russia in terms of intra-firm entrepreneurship, reflecting entrepreneurial initiatives implemented by employees of already-established organizations and associated with the development of new products and services within existing companies do not differ much either (Poland-1.9, Russia-0.9). The ratio of emerging entrepreneurs to those out of business is also similar (Poland-1.7, Russia-1.75). Despite the closeness of a number of indicators related to the similarity of informal institutions, the indicator reflecting the business motivation index calculated as the ratio of the share of highly pretentious entrepreneurs (those who see the advantages of doing their own business) to the share of forced ones is fundamentally different (Russia-0.9, Poland-6.8). This difference is undoubtedly due to "hard" institutions.

In our opinion, each region has its own unique architecture of the entrepreneurial ecosystem, and its efficiency in terms of generating and developing entrepreneurial processes is largely determined by the quality of the environment in which the ecosystem elements interact with each other. In this regard, we propose to assess the maturity of regional entrepreneurial ecosystems on the basis of the approach of D. Isenberg, including the "environment" position, assessed by qualitative indicators (Table 2). 
Table 2. Indicators for assessing ecosystem maturity.

\begin{tabular}{|c|c|c|c|}
\hline Indicators & Sub-Indicators & $\begin{array}{l}\text { Quantity/ } \\
\text { Quality }\end{array}$ & $\begin{array}{c}\text { Calculated Independently or Taken from } \\
\text { Other Sources }\end{array}$ \\
\hline \multirow{3}{*}{ Density } & $\begin{array}{l}\text { 1. The ratio of the number of new and } \\
\text { young firms to the working age } \\
\text { population of the region }\end{array}$ & Quantity & \multirow{3}{*}{$\begin{array}{l}\text { Calculated based on the data of the Federal } \\
\text { State Statistics Service (Rosstat) and the } \\
\text { Federal Tax Service of Russia }\end{array}$} \\
\hline & $\begin{array}{l}\text { 2. The share of new and young firms } \\
\text { in the region's employment }\end{array}$ & Quantity & \\
\hline & $\begin{array}{l}\text { 3. The ratio of business angels to the } \\
\text { number of entrepreneurial firms in } \\
\text { the region }\end{array}$ & Quantity & \\
\hline \multirow{3}{*}{ Fluidity } & $\begin{array}{l}\text { 4. The share of high-growth firms in } \\
\text { the region (based on firm turnover) }\end{array}$ & Quantity & \multirow{3}{*}{$\begin{array}{l}\text { Calculated based on the data of the Federal } \\
\text { State Statistics Service (Rosstat) and the } \\
\text { Federal Tax Service of Russia }\end{array}$} \\
\hline & $\begin{array}{l}\text { 5. The share of entrepreneurs in } \\
\text { the market }\end{array}$ & Quantity & \\
\hline & 6. Labor market mobility & Quantity & \\
\hline \multirow[t]{2}{*}{ Diversity } & $\begin{array}{l}\text { 7. The level of diversification of the } \\
\text { small and medium-sized enterprises } \\
\text { (SMEs) sector (number of industries } \\
\text { presented in the region) }\end{array}$ & Quantity & \multirow{2}{*}{$\begin{array}{l}\text { Calculated based on data from the Unified } \\
\text { Interdepartmental Statistical Information } \\
\text { System (UISIS) and the Federal Tax Service of } \\
\text { Russia }\end{array}$} \\
\hline & 8. The share of high-tech industries & Quantity & \\
\hline \multirow{3}{*}{ Connectivity } & $\begin{array}{l}\text { 9. The level of entrepreneurial } \\
\text { recycling in the region (number of } \\
\text { closed firms to total) }\end{array}$ & Quantity & \multirow{3}{*}{$\begin{array}{l}\text { Calculated based on the data of the Federal } \\
\text { State Statistics Service (Rosstat), the Federal } \\
\text { Tax Service of Russia and the Business Support } \\
\text { Centre in the Penza region } \\
\text { https:/ / cpp.mbpenza.ru/ }\end{array}$} \\
\hline & $\begin{array}{l}\text { 10. The level of entrepreneurial } \\
\text { collaboration within the region }\end{array}$ & Quality & \\
\hline & $\begin{array}{l}\text { 11. The number of support and } \\
\text { development programs for new firms } \\
\text { and fast-growing ones within } \\
\text { the region }\end{array}$ & Quantity & \\
\hline \multirow{3}{*}{$\begin{array}{l}\text { Entrepreneurial } \\
\text { Environment }\end{array}$} & $\begin{array}{l}\text { 12. An assessment of entrepreneurial } \\
\text { culture and education in the region }\end{array}$ & Quality & \multirow{3}{*}{$\begin{array}{l}\text { Identified by experts based on the Global } \\
\text { Entrepreneurship Monitor (GEM) } \\
\text { methodology } \\
\text { https://gsom.spbu.ru/gsom/research_- } \\
\text { statistics/gem/ }\end{array}$} \\
\hline & $\begin{array}{l}\text { 13. An assessment of motivation for } \\
\text { entrepreneurial activity in the region }\end{array}$ & Quality & \\
\hline & $\begin{array}{l}\text { 14. Entrepreneurial opportunities in } \\
\text { the region }\end{array}$ & Quality & \\
\hline
\end{tabular}

The calculation of the integral index of the maturity of the regional entrepreneurial system was made on the basis of multidimensional ranking. The model methodology allows the use of both quantitative and qualitative data. To build a multidimensional ranking of regional entrepreneurial ecosystems, indicators reflecting the level of ecosystem maturity were used. When selecting the appropriate indicators, the authors relied on the previously identified factors of entrepreneurship development in the Global Entrepreneurship Monitor project. The list of indicators and their number were selected based on the availability of data in two countries.

Thus, five thematic groups (blocks) of sub-indicators that characterize the level of maturity of entrepreneurial ecosystems are formed.

Connectivity is meant as the interconnection between entrepreneurs with other companies and organizations. Connectivity can be assessed through the number of programs to support and develop entrepreneurship in the region.

Diversity means that regions specializing in multiple economic areas should achieve greater entrepreneurial outcomes than those that only specialize in one or two industries. 
Entrepreneurial opportunities are favorable conditions for starting a business in the regions. The development of initiatives aimed at expanding opportunities for people interested in entrepreneurship is a critical factor for the growth of entrepreneurial activity in the regions.

The problem of assessing the level of maturity of ecosystems is that of reasonable selection of sub-indicators, finding gradations and assessment scales of the maturity level. As a result, an objective assessment system is being developed, which is the basis for conducting a set of information, obtaining an integral quantitative assessment of the state of the regional entrepreneurial ecosystem.

An algorithm for assessing the maturity of an entrepreneurial ecosystem is shown in Figure 3.

Step 1. Calculation of sub-indices in accordance with D. Eisenberg's approach for the positions "density", "variability", "diversity" and "connectivity" for each region.

Step 2. Expert assessment of indicators for the "environment" position for each region

Step 3. Calculation of the sub-index for the indicators of the position "environment" for each region using the method hierarchies

Step 4. Formation of the scale of maturity of the regional entrepreneurial ecosystem

Step 5. Calculation of the integral index of the maturity of the regional entrepreneurial system

Step 6. Assessment of the maturity of the regional entrepreneurial ecosystem according to the obtained integral indices for each region

Step 7. Calculation of the integral index of the maturity of the regional entrepreneurial system to an index of sustainable development in each region

Step 8. Analysis of the results obtained and development of recommendations.

Figure 3. Stages of assessing the maturity of the regional entrepreneurial ecosystem. Source: Own elaboration.

The sub-indicators are transformed into an integral indicator for each block by means of standardization, aggregation, and weighting operations.

The indicators are obtained as the arithmetic mean of sub-indicators for each of the blocks:

$$
I_{i}=\sqrt[k]{\sum I_{i}}
$$

where $I_{j}$ is the integral indicator of the $j$-th block; $I_{i}$ are sub-indicators; $k$ is the number of sub-indicators in each block, $k=1, \ldots . ., n$.

Quality sub-indicators were assessed using the Global Entrepreneurship Monitor methodology. The experts gave from one to nine points on the Likert scale for three indicators: entrepreneurial culture and education; the level of motivation for entrepreneurial activity; entrepreneurial opportunities. The experts' estimates were obtained in the framework of scientific research by the Penza State University (Russia) and the AGH University of Science and Technology (Poland).

The level of maturity of the regional entrepreneurial ecosystem was assessed using the formula:

$$
I_{M}=\sqrt[n]{I_{D e n}} \cdot I_{F} \cdot I_{D i v} \cdot I_{C} \cdot I_{E}
$$


where $I_{M}$ is the maturity index of the regional entrepreneurial ecosystem; $I_{D e n}, I_{F}, I_{D i v}$, $I_{C}, I_{E}$ are integral indicators for five blocks: density, fluidity, diversity, connectivity, entrepreneurial environment; $n$ is the number of blocks, from 1 to $k$.

Furthermore, the authors have attempted to establish the interconnection between the level of maturity of entrepreneurial ecosystems and sustainable development of the region. The proposed matrix "maturity—sustainable development" is based on the International Standard for Sustainable Development in Communities ISO/DIS37101 and the Russian Standard GOST R 54598.1-2011 [56]. The matrix connects the basic principles of sustainable development of territories and the level of maturity of the territory's entrepreneurial ecosystems. A generalized desirability function (d-function) is found on the basis of the integral assessment. The desirability scale establishes a correspondence between a numerical and an empirical preference pattern. According to the Harrington Desirability Scale, the standard marks range from 0 to 1 . Table 3 shows the interconnection between the levels of maturity of entrepreneurial ecosystems and sustainable development in the region.

Table 3. Scale of maturity of the regional entrepreneurial ecosystem.

\begin{tabular}{|c|c|c|}
\hline An Ecosystem Maturity Level & $\begin{array}{l}\text { Maturity Index/Sustainable } \\
\text { Development Index }\end{array}$ & Sustainable Development \\
\hline $1 \mathrm{st}$ & $1.00-0.80$ & Strong \\
\hline 2nd & $0.80-0.63$ & Weak \\
\hline 3rd & $0.63-0.37$ & Unsustainable \\
\hline 4 th & $0.37-0$ & Stagnation \\
\hline
\end{tabular}

Limitations and assumptions:

1. Integral indices have a greater statistical error than their constituent indices make. An index is meant as the result of information set about the system, that is, a mathematical function based on two or more variables.

2. The list of sub-indicators is formed on the basis of available data in the studied regions.

3. The correctness of using the integral assessment to determine the level of maturity of the regional entrepreneurial ecosystem is determined by the correctness of its interpretation.

\section{Case Study}

\subsection{Description of the Entrepreneurial Ecosystems of the Penza Region and the Matopolska Region}

The Małopolska region is located in the south of Poland. It borders with Slovakia and three other Polish provinces: Ślaskie, Świętokrzyskie and Podkarpackie. It is one of the smallest voivodship in Poland (less than 15.2 thousand $\mathrm{km}^{2}$ ). However, it is also the most densely populated: there are about 220 people per square kilometer. The main cities are Kraków, which is the capital of the voivodship, Tarnów and Nowy Sacz.

The region has the third highest growth rate of Gross Domestic Product in Poland. There are approximately 1.5 million economically active persons. Moreover, about $70 \%$ of working age people are economically active. Only in 2019 almost 37 thousands of new companies were registered. This number has been increasing lately. There are about 15 thousand people employed in R\&D activities. 
The regulations of the EU regarding the free movement of services and products make it easier for entrepreneurs to start business activity in other than Poland the EU countries. New and young firms have an opportunity to increase income and profit through the single market of the European Union because of low labor costs and quite high innovative levels.

Creating clusters and cooperation networks in the developed countries turned out to be a very effective and efficient form of supporting the development of high-growth firms. Similar initiatives are more and more popular in Małopolska. However, there is still a need for wider support for these activities.

The cooperation between research and development institutions and enterprises allows for introducing the developed technologies to the market. It also allows the inflow of funds to the former, enabling them to continue R\&D work. However, this cooperation in the period of economic transformation has significantly worsened. Meanwhile, Małopolska has a great scientific and research potential. Stimulating this cooperation, along with the use of the EU funds, is therefore an opportunity for the development both for Małopolska high-growth companies, and scientific and research centers.

The number of companies in such sectors as hotels and restaurants, manufacturing, construction, and transport is also higher than in other regions of Poland. Nowadays, most companies in Malopolska face the challenge of transforming from an imitative to an innovative economic development process. According to the current classification in the Regional Innovation Scoreboard of the European Commission, the region is a "Moderate Innovator".

4.2. An Assessment of the Level of Entrepreneurial Ecosystem Development in the Penza Region (Russia) and the Matopolska Region (Poland)

The article uses the following official data as an information source (Tables 4 and 5):

(1) The Federal State Statistics Service (Rosstat) https: / / www.gks.ru/folder /10705;

(2) The Unified Interdepartmental Statistical Information System (UISIS) https:/ fedstat.ru/;

(3) The Penza region investment portal http://investinpenza.com/About/Economy;

(4) The Business Support Centre in the Penza region https:/ / cpp.mbpenza.ru/;

(5) Development institutions and public organizations to support entrepreneurship in the Penza region https:/ / mbpenza.ru/infrastruktura;

(6) Penza Business Angels Association http://inno-terra.ru/node/6549;

(7) Global Entrepreneurship Monitor (GEM) https://gsom.spbu.ru/gsom/research statistics/gem/;

(8) State Statistics Service of the Małopolska region https:/ / www.malopolska.pl, https:/ / www.stat.gov.pl;

(9) Startup Support Centers in the Małopolska region https:/ / www.omgkrk.com/ krakowstartups, https:/ / startupacademy.pl/startup-malopolska.

The integral indicators of density, fluidity, diversity, connectivity, and entrepreneurial environment for the Małopolska and the Penza regions were calculated using Formula (1) (Table 6). The maturity index was calculated according to Formula (2).

The highest value of the maturity index of the entrepreneurial ecosystem was 0.939 in the Małopolska region in 2019-Table 6. The main factors that influenced the growth of the maturity index in dynamics are entrepreneurial environment and connectivity. The connectivity indicator increased from 1.280 in 2015 to 1.360 in 2019, which indicates a significant improvement in the conditions for entrepreneurs to interact with other organizations, and growth in the number of programs for the development and support of entrepreneurship in the Małopolska region. The lowest value of the maturity index of the entrepreneurial ecosystem in the Małopolska region was in 2016 (0.813) due to a significant decrease in the value of the fluidity indicator. 
Table 4. Initial data for assessing the maturity of the Małopolska region entrepreneurial ecosystem.

\begin{tabular}{|c|c|c|c|c|c|}
\hline Sub-Indicators & 2015 & 2016 & 2017 & 2018 & 2019 \\
\hline \multicolumn{6}{|c|}{ Density } \\
\hline Number of new and young firms & 33,201 & 32,451 & 34,045 & 37,214 & 36,738 \\
\hline $\begin{array}{l}\text { New and young firms per } 1000 \text { of working } \\
\text { age population }\end{array}$ & 9.85 & 9.61 & 10.05 & 10.96 & 10.79 \\
\hline Number of employees in new and young firms & 523,245 & 550,894 & 564,863 & 580,503 & 594,313 \\
\hline Number of working age population, people & 865,369 & 906,166 & 936,159 & 954,956 & 982,542 \\
\hline Total number of employees in the region, people & 800,257 & 848,571 & 855,132 & 857,950 & 873,120 \\
\hline Number of entrepreneurial firms & 177,569 & 187,692 & 193,435 & 202,741 & 205,604 \\
\hline Number of business angels in the region & 13 & 13 & 11 & 14 & 16 \\
\hline \multicolumn{6}{|c|}{ Fluidity } \\
\hline Number of high-growth firms & 545 & 620 & 715 & 780 & 830 \\
\hline Number of entrepreneurs & 265,355 & 267,195 & 272,550 & 285,802 & 300,589 \\
\hline Coefficient of migration growth per 10,000 inhabitants & 0.13 & 0.29 & 0.27 & 0.27 & 0.3 \\
\hline \multicolumn{6}{|c|}{ Diversity } \\
\hline Number of industries represented by entrepreneurship & 5 & 5 & 6 & 6 & 6 \\
\hline Number of high-tech industries & 3 & 3 & 3 & 3 & 3 \\
\hline \multicolumn{6}{|c|}{ Connectivity } \\
\hline Number of closed firms in the region & 25,869 & 25,259 & 24,948 & 25,244 & 18,046 \\
\hline Entrepreneurial collaboration within the region & 6.3 & 6.5 & 6.9 & 7.5 & 7.7 \\
\hline $\begin{array}{l}\text { Number of programs to support and develop new and } \\
\text { fast-growing firms within the region }\end{array}$ & 14 & 14 & 12 & 12 & 15 \\
\hline \multicolumn{6}{|c|}{ Entrepreneurial environment } \\
\hline Entrepreneurial culture, point & 4.8 & 5.0 & 5.1 & 5.3 & 5.4 \\
\hline Motivation for entrepreneurial activity, point & 7.2 & 7.4 & 7.4 & 7.8 & 8.0 \\
\hline Entrepreneurial opportunities, point & 7.0 & 6.7 & 6.8 & 6.5 & 6.9 \\
\hline
\end{tabular}

Table 5. Initial data for assessing the maturity of the Penza region entrepreneurial ecosystem.

\begin{tabular}{cccccc}
\hline Sub-Indicators & $\mathbf{2 0 1 5}$ & $\mathbf{2 0 1 6}$ & $\mathbf{2 0 1 7}$ & $\mathbf{2 0 1 8}$ & \\
\hline & Density & & & \\
\hline Number of new and young firms & 6985 & 7131 & 7459 & 7966 \\
\hline Number of employees in new and young firms & 135,725 & 134,618 & 132,863 & 132,285 & 123,654 \\
\hline Number of working age population, thousands & 740.1 & 739.9 & 724.9 & 708.3 & 702.1 \\
\hline $\begin{array}{c}\text { Total number of employees in the region, thousand } \\
\text { people }\end{array}$ & 605.7 & 604.8 & 606.6 & 604.8 \\
\hline Number of the entrepreneurial firms & 45,962 & 46,798 & 47,231 & 46,521 & 45,020 \\
\hline Number of business angels in the region & 9 & 11 & 13 & 10 & 12 \\
\hline
\end{tabular}


Table 5. Cont.

\begin{tabular}{|c|c|c|c|c|c|}
\hline Sub-Indicators & 2015 & 2016 & 2017 & 2018 & 2019 \\
\hline \multicolumn{6}{|c|}{ Fluidity } \\
\hline Number of high-growth firms & 1659 & 1872 & 1886 & 1860 & 1800 \\
\hline Number of entrepreneurs & 39,762 & 40,143 & 31,301 & 30,930 & 30,504 \\
\hline Coefficient of migration growth per 10,000 inhabitants & -8 & -10 & -22 & -44 & -49 \\
\hline \multicolumn{6}{|c|}{$\begin{array}{ll} & \text { Diversity } \\
\end{array}$} \\
\hline Number of industries represented by entrepreneurship & 5 & 7 & 6 & 6 & 7 \\
\hline Number of high-tech industries & 2 & 2 & 3 & 3 & 3 \\
\hline \multicolumn{6}{|c|}{ Connectivity } \\
\hline Number of closed firms in the region & 32,173 & 23,399 & 27,785 & 25,260 & 33,765 \\
\hline Entrepreneurial collaboration within the region & 3.8 & 4.2 & 4.8 & 4.8 & 4.9 \\
\hline $\begin{array}{l}\text { Number of programs to support and develop new and } \\
\text { fast-growing firms within the region }\end{array}$ & 6 & 8 & 8 & 10 & 11 \\
\hline \multicolumn{6}{|c|}{ Entrepreneurial environment } \\
\hline Entrepreneurial culture, point & 4.1 & 4.3 & 4.4 & 4.5 & 4.5 \\
\hline Motivation for entrepreneurial activity, point & 3.6 & 4.0 & 4.1 & 4.3 & 4.4 \\
\hline Entrepreneurial opportunities, point & 5.2 & 5.2 & 5.7 & 5.7 & 5.8 \\
\hline
\end{tabular}

Table 6. Calculating the results of indicators for assessing the maturity of entrepreneurial ecosystems in the Penza and the Małopolska regions.

\begin{tabular}{cccccccccccccc}
\hline \multirow{2}{*}{ Indicators } & \multicolumn{4}{c}{ Małopolska Region } & \multicolumn{4}{c}{ Penza Region } \\
\cline { 2 - 10 } & $\mathbf{2 0 1 5}$ & $\mathbf{2 0 1 6}$ & $\mathbf{2 0 1 7}$ & $\mathbf{2 0 1 8}$ & $\mathbf{2 0 1 9}$ & $\mathbf{2 0 1 5}$ & $\mathbf{2 0 1 6}$ & $\mathbf{2 0 1 7}$ & $\mathbf{2 0 1 8}$ & $\mathbf{2 0 1 9}$ \\
\hline Density & 0.468 & 0.279 & 0.284 & 0.291 & 0.418 & 0.431 & 0.421 & 0.423 & 0.435 & 0.429 \\
\hline Fluidity & 1.176 & 0.951 & 1.189 & 1.190 & 1.209 & 0.936 & 0.961 & 0.785 & 0.642 & 0.611 \\
\hline Diversity & 1.164 & 1.161 & 1.177 & 1.176 & 1.167 & 1.219 & 1.213 & 1.247 & 1.239 & 1.296 \\
\hline Connectivity & 1.280 & 1.290 & 1.250 & 1.280 & 1.360 & 0.980 & 1.100 & 1.120 & 1.200 & 1.360 \\
\hline $\begin{array}{c}\text { Entrepreneurial } \\
\text { environment }\end{array}$ & 0.889 & 0.891 & 0.894 & 0.898 & 0.909 & 0.782 & 0.794 & 0.807 & 0.813 & 0.816 \\
\hline Maturity index $\left(I_{M}\right)$ & 0.938 & 0.813 & 0.859 & 0.860 & 0.939 & 0.823 & 0.844 & 0.821 & 0.805 & 0.806 \\
\hline
\end{tabular}

On the whole, the value of the maturity index had a positive trend and varied in the range from 0.859 to 0.939 in other periods. The higher the maturity index of the entrepreneurial ecosystem is, the better conditions are created for the development of entrepreneurship in the region.

In the Penza region, the highest (0.844) and lowest (0.805) values of the entrepreneurial ecosystem maturity index was in 2016 and 2018, respectively. The index has a negative trend and has been declining since 2017. The analysis carried out by the method of chain substitution made it possible to identify the primary and secondary factors influencing the maturity index. Despite a slight increase in the values of most indicators, the maturity index decreases due to fluidity. In the Penza region, in the period from 2015 to 2019, there was an exodus of the working age population, and the mobility of the labor market had negative values. In addition, the share of high-growth firms in the region decreased in 2019 compared to 2018, and the number of entrepreneurs also decreased.

Figure 4 shows the maturity profile of entrepreneurial ecosystems in the Małopolska and the Penza regions in 2015 and 2019, compared to the reference value. 
Maturity profiles, 2015

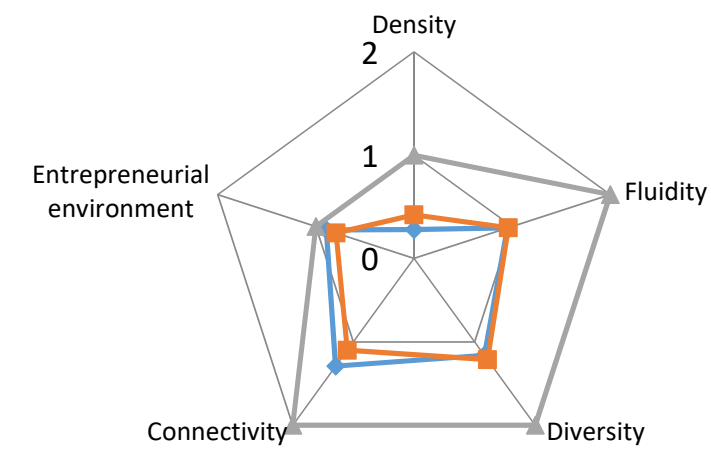

$\longrightarrow$ Malopolsky $\longrightarrow$ Penza $\_$Reference level of maturity indicators
Maturity profiles, 2019

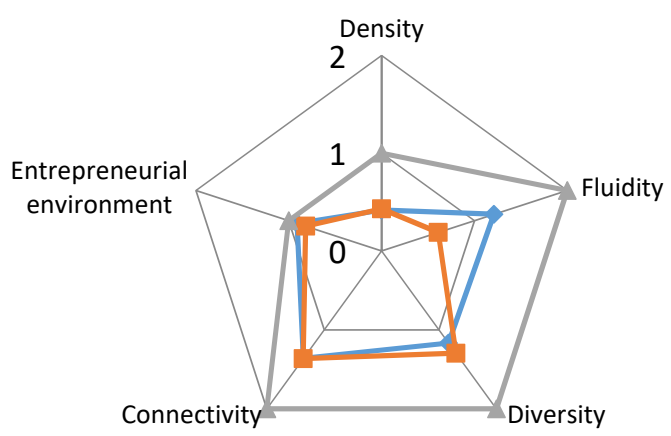

$\longrightarrow$ Malopolsky $\longrightarrow$ Penza $\longrightarrow$ Reference level of maturity indicators

Figure 4. Maturity profiles of the entrepreneurial ecosystems in the Małopolska and the Penza regions (2015, 2019). Source: Own elaboration.

If we consider the obtained results in the context of the practical implementation of sustainable development goals, then particular attention is drawn to the indicators of fluidity, connectivity, and the entrepreneurial environment. Improving the quality of the entrepreneurial environment and creating conditions for the development of ecosystem actors has a direct impact on the maturity of regional entrepreneurial ecosystems, and an indirect one on the sustainable development of regions (Table 7). The indirect impact is to help achieve Sustainable Development Goals (SDGs) 8 (Decent Work and Economic Growth) and SDGs 17 (Partnership for Sustainable Development) [59,60].

Table 7. Interconnection between the maturity of regional entrepreneurial ecosystem and sustainable development of the region.

\begin{tabular}{|c|c|c|c|c|c|c|c|c|c|c|}
\hline \multirow{2}{*}{ Indicators } & \multicolumn{5}{|c|}{ Małopolska Region } & \multicolumn{5}{|c|}{ Penza Region } \\
\hline & 2015 & 2016 & 2017 & 2018 & 2019 & 2015 & 2016 & 2017 & 2018 & 2019 \\
\hline Maturity index $\left(I_{M}\right)$ & 0.938 & 0.813 & 0.859 & 0.860 & 0.939 & 0.823 & 0.844 & 0.821 & 0.805 & 0.806 \\
\hline $\begin{array}{c}\text { Sustainable Development } \\
\text { Index }\left(I_{S}\right)\end{array}$ & 0.618 & 0.624 & 0.639 & 0.692 & 0.715 & 0.482 & 0.500 & 0.517 & 0.508 & 0.514 \\
\hline
\end{tabular}

The rating of sustainable development of the regions of the Russian Federation is compiled by the SGM agency annually in accordance with the principles of sustainable development of territories determined by international organizations and the scientific community [61]. The index of sustainable development (ISD) of territories is calculated on the basis of 42 statistical indicators characterizing the development of regions in five main blocks: economic development, industrial infrastructure, demography, social infrastructure, and ecology.

The rating of sustainable development of the regions in Eastern Europe was compiled by the Eurostat agency [62] and the Ministry of Investment and Economic Development of Poland [63].

In accordance with the scale (Table 3), the entrepreneurial ecosystem of the Penza region developed unstably in 2015-2016, and since 2017, the development can be characterized as weak sustainability, which corresponds to the second level of ecosystem maturity. During the study period, the Małopolska entrepreneurial ecosystem was in the zone of weak sustainable development, with the exception of 2018, when a strong sustainability corresponding to the first level of ecosystem maturity was achieved. 


\section{Discussion and Conclusions}

The concept of entrepreneurial ecosystems is nowadays an important subject of entrepreneurship research. However, the contribution of ecosystems to the Sustainable Development Goals (SDGs) set by the United Nations is not a detectable issue in the academic literature [64].

The presented paper contributes to the academic literature by providing a synthesis on territorial sustainable development research and the related concepts of innovation and entrepreneurial ecosystems. Moreover, a framework is proposed for the assessment of regional sustainability, replicating and expanding the approach of D. Isenberg. In addition, it enhances the existing literature in the field of New Institutional Economies as the paper draws inference to the impact of institutional environments on the configuration and practices of EEs through the application of institutional theoretical perspectives. Therefore, the paper proposes an approach to the analysis of territorial sustainable development in the context of regional specificities via assessing the level of entrepreneurial ecosystem maturity in Russia and Poland (the Penza region and the Małopolska region).

The interconnection between the level of maturity of entrepreneurial ecosystems and sustainable development in the region presented in the matrix "maturity-sustainable development" is based on the International Standard for Sustainable Development in Communities ISO/DIS37101 and the Russian Standard GOST R 54598.1-2011.

We conducted two empirical case studies of entrepreneurial ecosystems of Penza and Małopolska regions in Russia and Poland according to the proposed method.

As a result of the analysis, the maturity profiles of entrepreneurial ecosystems in the studied regions were elaborated. If we consider the obtained results in the context of the practical implementation of sustainable development goals, then particular attention is drawn to the indicators of fluidity, connectivity, and the entrepreneurial environment. Improving the quality of the entrepreneurial environment and creating conditions for the development of ecosystem actors has a direct impact on the maturity of regional entrepreneurial ecosystems, and an indirect one on the sustainable development of regions. The indirect impact is to help achieve Sustainable Development Goals (SDGs) 8 (Decent Work and Economic Growth) and SDGs 17 (Partnership for Sustainable Development).

The authors assume that the regions specializing in multiple economic areas should enjoy greater entrepreneurial outcomes than those that only specialize in one or two industries. Our research is not the first to investigate this aspect of regional entrepreneurship development. Previous studies have found a positive relationship between key development indicators in different regions and the related variety [65-67].

Frenken et al. [68] argues that regions with a high degree of interconnected diversity are more likely to increase employment. This can make regions more resilient to industrial changes and external challenges. The results of our study correlate with the works of the above authors, and confirm that diversity in economic areas has a positive effect on the sustainable development of the region as a whole, including the economic, environmental, and social components.

An important result of this work is the understanding of the informal institutional elements in order to promote the innovative sustainable development of the regions. Motivation for entrepreneurial activity and culture for open innovation as a "critical driver of innovation" [69] are also important in the progress of sustainable development. The culture for open innovation among entrepreneurs can decrease the cost of open innovation dynamics, also known as innovation complexity or the open innovation paradox, for both SMEs and big businesses [69]. The development of entrepreneurship open innovation culture in the regions can help stakeholders to collaborate effectively within the system and to more actively work with external parties [70].

Belussi and co-authors investigated the existence of an Open Regional Innovation System (ORIS) where the firms are adopt an open innovation strategy, which overcomes not only the boundaries of the firms but also the boundaries of the region through different external research networks and knowledge sources. Using the example of the Emilia 
Romagna ORIS, the authors prove that innovation openness influences significantly the firms' innovative performance [71].

From a policy support point of view, it seems very important to stimulate the development of territorial ecosystems based on trust, the exchange of knowledge and the sense of identity, which will allow the progression of sustainable development practices [6,72]. The prevalence of open innovation and open business models increases the importance of undocumented tacit knowledge that is achieved through face-to-face contact among people within the same territorial ecosystem [73].

It is crucial to emphasize that within the open innovation framework and globalization trends, it becomes necessary for regional authorities to provide companies with access to knowledge and technology and to connect innovation strategies with regional knowledge capabilities [74]. The model of society development based on knowledge transfer in conditions of the COVID-19 pandemic and the growing economic crisis is becoming especially relevant. In these conditions, the state should create a barrier-free friendly environment where an unhindered exchange of knowledge and information will take place, while ensuring the protection of the rights and interests of all stakeholders involved in the open collaboration processes. The concept of open innovation is a kind of development of the practice and methodology of knowledge transfer allowing a systematic look at the company's business model, taking into account the need to develop innovative products. Co-production of knowledge for project implementation in EEs is a driver of innovation. New knowledge must reflect the cutting edge of research in a specific area so that businesses and other stakeholders can meet global challenges.

If the object of regional innovation policy will be the ecosystem as a whole, rather than individual enterprises, the measures of state support, in our opinion, will be more fairly distributed, and take into account the importance of human capital, intellectual property, competition and public information in the development of open entrepreneurial ecosystems. The state should stop focusing on large markets and subsidizing especially big organizations. In such conditions, it will be easier for SMEs to develop and integrate into value chains on favorable terms.

It is expedient to develop measures of state support for open innovations, focusing on the stage of the life cycle [8] and the level of maturity of the entrepreneurial ecosystem. Open innovations successfully develop only in mature ecosystems, since the most important factor is the entrepreneurial institutional environment (entrepreneurial culture and opportunities for entrepreneurial development), which is formed over years or even decades.

To "standardize" the desired "sustainable behavior" of economic players in ecosystems, it seems possible to develop special measures of state support for certain categories of entrepreneurs. For example, SMEs developing creative technologies, approved at the level of national documents and development programs, should be supported by special measures of state support.

In entrepreneurial ecosystems, public-private partnerships (PPP) make it possible to create a portfolio of unique technologies and developments in areas in which long-term competitive advantages can be provided to obtain consistently high profits. Subsequently, based on the accumulated accelerated groundwork, actors form a technology transfer, providing a continuous innovation process.

The PPP mechanism is also advisable to use for the development of digital and platform solutions in ecosystems in order to establish effective communication channels between participants and to attract additional investment for the implementation of projects by increasing the transparency of information about investment opportunities. In addition, in conditions of economic instability, the PPP mechanism allows the use of new methods of project financing that can attract additional extrabudgetary funds to ecosystems, including infrastructure crowdfunding.

Today the world is at the stage of a humanitarian and technological revolution [75], the main goal of which is not technological development, not economic growth, but im- 
proving the quality of life of the population. Sustainable entrepreneurship development is increasingly based on collaboration through dynamic and open ecosystem platforms. This allows to connect all actors and ensure their co-evolution in the process of co-creation of value on the way to sustainable development of society. Effective public policy measures are aimed at supporting entrepreneurial ecosystems and will allow the faster achievement of the SDGs at the state level as a whole.

Ecosystems (entrepreneurial, sectoral, innovative, etc.) can form a special development of the environment and link cities and centers of industrial production with remote areas (local communities). Thus, we can conclude that sustainable ecosystems contribute to the development of local communities and affect the sustainable development of the entire country.

Hence, this paper contributes to the development of research concepts of the contextualization of entrepreneurship and sustainability in terms of elaboration of the approach for the assessment of regional sustainability via the maturity level of entrepreneurial ecosystems, which could fill the gap in the sustainable development research. From a theoretical point of view, the study encourages further research in order to introduce a strategic framework that could be able to identify different strategies for territorial sustainable outcomes.

The practical implications from the results of this study is the proposal of the approach to help regional authorities to progress sustainably and to understand ways in which to monitor current capabilities and emerging opportunities. Furthermore, it may also be useful for policymakers who are responsible for the evaluation of regional sustainable development and want to change entrepreneurial environment to progress sustainably and to achieve the SDGs.

\section{Limitations and Future Research Directions}

The presented study is the beginning of a discussion into the meaning of environmental and socio-economic development, and methods of measurements.

The proposed methodology is based on the following assumptions and limitations:

1. Integral indices have a greater statistical error than their constituent indices make.

An index is meant as the result of information set out in the system, that is, a mathematical function based on two or more variables.

2. The list of sub-indicators is formed on the basis of available data in the studied regions.

3. The accuracy of using the integral assessment to determine the level of maturity of the regional entrepreneurial ecosystem is determined by the accuracy of its interpretation.

Additionally, this paper is focused on a static analysis and does not scrutinize the logical relationship between the indexes and their evaluation.

Therefore, the authors suggest further research focused on research gaps in the EE literature with regard to support mechanisms and resources, institutional and network perspectives, and the performance evaluations of EEs.

Furthermore, when assessing a regional entrepreneurial ecosystem maturity and its sustainable development level, it is advisable to divide the regions into groups according to their socio-economic development and industrial specialization.

In addition, the authors plan to carry out further research into the development of open innovation models, integrating the main provisions of the quadruple helix theory with the principles of sustainable development and the innovation ecosystem model.

An important aspect of this study is also taking into account the connectivity factor (entrepreneurial collaboration within the region) when assessing the entrepreneurial ecosystem, and ultimately when determining the level of sustainable development of the region. It is of particular interest to include regional interconnections in the analysis and assessment of the maturity level of an ecosystem. In the context of future research, it is reasonable to study and develop approaches to assess spillover effects (vertical and horizontal) at the interregional level resulting from the collaboration of all stakeholders within an EE. Spatial econometrics may be applied to achieve this objective [76]. 
A study of the trust factor between stakeholders (interpersonal trust) and institutional trust on the closeness of collaboration and the effectiveness of ecosystem interactions is also of considerable scientific interest.

Author Contributions: Conceptualization, methodology, formal analysis, supervision, T.T.; conceptualization, elaborated the literature review, writing—original draft preparation, writing-review \& editing, L.G.; writing — original draft preparation, collected data, data validation, performed the first data analyses, N.S.; writing-original draft preparation, collected data, data validation, performed the first data analyses, M.W.; writing - original draft preparation, collected data, data validation, S.V. All authors have read and agreed to the published version of the manuscript.

Funding: This research was funded by the RFBR grant No. 20-010-00470.

Institutional Review Board Statement: Not applicable.

Informed Consent Statement: Not applicable.

Data Availability Statement: Not applicable.

Conflicts of Interest: The authors declare no conflict of interest.

\section{References}

1. Nijkamp, P.; Soeteman, F. Land Use, Economy and Ecology; (Serie Research Memoranda; No. 1989-48); Faculty of Economics and Business Administration, Vrije Universiteit Amsterdam: Amsterdam, The Netherlands, 1989.

2. Nijkamp, P.; van den Bergh, C.J.M.; Soeteman, F. Regional Sustainable Development and Natural Resource Use. World Bank Econ. Rev. 1990, 4, 153-188. [CrossRef]

3. Costa, J.; Matias, J.C. Open Innovation 4.0 as an Enhancer of Sustainable Innovation Ecosystems. Sustainability 2020, $12,8112$. [CrossRef]

4. Chaminade, C.; Randelli, F. The Role of Territorially Embedded Innovation Ecosystems Accelerating Sustainability Transformations: A Case Study of the Transformation to Organic Wine Production in Tuscany (Italy). Sustainability 2020, $12,4621$. [CrossRef]

5. Tolstykh, T.; Shmeleva, N.; Gamidullaeva, L. Evaluation of Circular and Integration Potentials of Innovation Ecosystems for Industrial Sustainability. Sustainability 2020, 12, 4574. [CrossRef]

6. Tolstykh, T.; Gamidullaeva, L.; Shmeleva, N.; Lapygin, Y. Regional Development in Russia: An Ecosystem Approach to Territorial Sustainability Assessment. Sustainability 2020, 12, 6424. [CrossRef]

7. Tolstykh, T.; Gamidullaeva, L.; Shmeleva, N. Elaboration of a Mechanism for Sustainable Enterprise Development in Innovation Ecosystems. J. Open Innov. Technol. Mark. Complex. 2020, 6, 95. [CrossRef]

8. Tolstykh, T.; Gamidullaeva, L.; Shmeleva, N. Approach to the Formation of an Innovation Portfolio in Industrial Ecosystems Based on the Life Cycle Concept. J. Open Innov. Technol. Mark. Complex. 2020, 6, 151. [CrossRef]

9. Gamidullaeva, L. Towards Combining the Innovation Ecosystem Concept with Intermediary Approach to Regional Innovation Development. Int. J. Econ. Bus. Adm. 2018, 6, 39-53.

10. Isenberg, D. The Entrepreneurship Ecosystem Strategy as a New Paradigm for Economic Policy: Principles for Cultivating Entrepreneurship. Babson Entrepreneurship Ecosystem Project. Dublin, from Dan Isenberg. 2011. Available online: http: / / urlid.ru/afpg (accessed on 12 November 2020).

11. North, D.C. Institutions, Institutional Change and Economic Performance. 1990. Available online: https://www.cambridge. org/core/books/institutions-institutional-change-and-economic-performance/AAE1E27DF8996E24C5DD07EB79BBA7EE? _cf_chl_jschl_tk_=17e39b49e85af092478c542261e5229c2d49573f-1608611022-0-AVad51DUyuXFHwm9fHIZv62rhaoDBdKa_gKfWo95SywhQrjvmDKM0HqfvsWwuFe20u9g44mMBJ1WnYR6m3mNte8odjIBY4syRtkOp9k8OUvpVK2dHCq--F7 MteUoXUhXUBSdw4tDGGWHGp92ucuqSXX8g-xkxTbLj4XzAGbNwYd1GHBZ-fxEc_NKUu2Wcw0pMr3w5C9h8Tz1Snm6 YiPv8lHVwkC1lgW-XuxKt1wUL3uurZQgoLrlyHM_jALds9JOrYfN0Pv4T1qtYFvQxR-mz0j65XdkVP0UM6rIo2EDtQR4 oCRUUgBUDXmf5xAxI8bl5Ui12hI0cP7rz96nHNsc20n-39rgMRYTlP22ePLeY7ikVqq9Yv1Ix8GFvtV9CJqOGqUby2UfBUHcJcNn6 JFsjVnvV8EiRVWqhsYtgVp5kqMrdgT9hXSegN6JpLRidTzHnQWCGulvogAlNuBGbSci6iUvfEfLWcDmqwWaOsliMStP5iGc9 nsUZ_UWovfo76okw (accessed on 12 November 2020).

12. Drucker, P.F. Innovation and Entrepreneurship: Practice and Principles; HarperBusiness: New York, NY, USA, 1985.

13. Szerb, L.; Lafuente, E.; Horváth, K.; Páger, B. The relevance of quantity and quality entrepreneurship for regional performance: The moderating role of the entrepreneurial ecosystem. Reg. Stud. 2019, 53, 1308-1320. [CrossRef]

14. Dutz, M. Unleashing India's Innovation: Towards Sustainable and Inclusive Growth; World Bank: Washington, DC, USA, 2007.

15. Brown, R.; Mason, C. Looking inside the spiky bits: A critical review and conceptualisation of entrepreneurial ecosystems. Small Bus. Econ. 2017, 49, 11-30. [CrossRef]

16. Pinkow, F.; Iversen, J. Strategic Objectives of Corporate Venture Capital as a Tool for Open Innovation. J. Open Innov. Technol. Mark. Complex. 2020, 6, 157. [CrossRef] 
17. Doroshenko, S.V.; Shelomentsev, A.G. Entrepreneurial ecosystem in modern socioeconomic research. J. Econ. Theory 2017, 4, 212-221.

18. Dubina, I.N.; Kozhevina, O.V.; Chub, A.A. Innovative and entrepreneurial ecosystems as a factor of regional development sustainability. Econ. Anal. Theory Pract. 2016, 4, 4-19.

19. Spilling, O.R. The entrepreneurial system: On entrepreneurship in the context of a mega-event. J. Bus. Res. 1996, 36, 91-103. [CrossRef]

20. Zemtsov, S.P.; Baburin, V.L. Entrepreneurial ecosystems in the regions of Russia. Reg. Stud. 2019, 2, 4-14. [CrossRef]

21. O'Connor, A.; Stam, E.; Sussan, F.; Audretsch, D. Entrepreneurial Ecosystems. Place-Based Transformations and Transitions; Springer: New York, NY, USA, 2018.

22. Stam, E. Entrepreneurial ecosystems and regional policy: A sympathetic critique. Eur. Plan. Stud. 2015, 9, 1759-1769. [CrossRef]

23. Wagner, J.; Sternberg, R. Start-up activities, individual characteristics, and the regional milieu: Lessons for entrepreneurship support policies from German micro data. Ann. Reg. Sci. 2004, 2, 219-240. [CrossRef]

24. Bruns, K.; Bosma, N.; Sanders, M.; Schramm, M. Searching for the existence of entrepreneurial ecosystems: A regional cross-section growth regression approach. Small Bus. Econ. 2017, 49, 31-54. [CrossRef]

25. Cohen, B. Sustainable valley entrepreneurial ecosystems. Bus. Strategy Environ. 2006, 15, 1-14. [CrossRef]

26. Audretsch, D.B.; Belitski, M. Entrepreneurial ecosystems in cities: Establishing the framework conditions. J. Technol. Transf. 2017, 42, 1030-1051. [CrossRef]

27. Qian, H.; Acs, Z.J.; Stough, R.R. Regional systems of entrepreneurship: The nexus of human capital, knowledge and new firm formation. J. Econ. Geogr. 2012, 13, 559-587. [CrossRef]

28. Stam, E.; Spigel, B. Entrepreneurial ecosystems. In The SAGE Handbook of Small Business and Entrepreneurship; Blackburn, R., De Clercq, D., Heinonen, J., Eds.; SAGE: London, UK, 2018; pp. 407-422.

29. Spigel, B. The relational organization of entrepreneurial ecosystems. Entrep. Theory Pract. 2017, 41, 49-72. [CrossRef]

30. Auerswald, P. Enabling Entrepreneurial Ecosystems. Insights from Ecology to Inform Effective Entrepreneurship Policy. The Oxford Handbook of Local Competitiveness; Oxford University Press: Oxford, UK, 2015.

31. Drabenstott, M.; Sheaff, K.H. Exploring policy options for a new rural America-A Conference Summary. Econ. Rev. 2001, $86,65-77$.

32. Neck, H.M.; Meyer, G.D.; Cohen, B.; Corbett, A.C. An entrepreneurial system view of new venture creation. J. Small Bus. Manag. 2004, 42, 190-208. [CrossRef]

33. Shwetzer, C.; Maritz, A.; Nguyen, Q. Entrepreneurial ecosystems: A holistic and dynamic approach. J. Ind. Univ. Collab. 2019, 1, 79-95. [CrossRef]

34. Malecki, E.J. Entrepreneurship and entrepreneurial ecosystems. Geogr. Compass 2018, 12, e12359. [CrossRef]

35. Greve, A.; Salaff, J.W. Social Networks and Entrepreneurship. Entrep. Theory Pract. 2003, 28, 1-22. [CrossRef]

36. Brundin, E.; Wigren, C.; Isaacs, E.; Friedrich, C.; Visser, K. Triple Helix Networks in a Multicultural Context: Triggers and Barriers for Fostering Growth and Sustainability. J. Dev. Entrep. 2008, 13, 77-98. [CrossRef]

37. Schilling, M.A.; Phelps, C.C. Interfirm Collaboration Networks: The Impact of Large-Scale Network Structure on Firm Innovation. Manag. Sci. 2007, 53, 1113-1126. [CrossRef]

38. Isenberg, D. Worthless, Impossible and Stupid: How Contrarian Entrepreneurs Create and Capture Extraordinary Value; Harvard Business Press: Oxford, UK, 2013.

39. Isenberg, D.; Onyemah, V. Fostering scaleup ecosystems for regional economic growth. Innov. Technol. Gov. Glob. 2016, 11, 60-79.

40. Ahmad, N.; Seymour, R. Defining Entrepreneurial Activity: Definitions Supporting Frameworks for Data Collection; OECD Statistics Working Paper; OECD: Paris, France, 2008; pp. 1-18.

41. Ács, Z.J.; Autio, E.; Szerb, L. National Systems of Entrepreneurship: Measurement issues and policy implications. Res. Policy 2014, 43, 476-494. [CrossRef]

42. Collin, M.; Ross, B. Entrepreneurial Ecosystems and Growth Oriented Entrepreneurship. OECD-LEED, U.S. Green Building Council: Washington, DC, USA, 2014. Available online: www.oecd.org/cfe/leed/entrepreneurial-ecosystems.pdf (accessed on 12 November 2020).

43. Stangler, D.; Bell-Masterson, J. Measuring an Entrepreneurial Ecosystems; The Kauffman Foundation Report; Kaufmann Foundation: Kansas, KS, USA, 2015; Available online: https://www.kauffman.org/wpcontent/uploads/2019/12/measuring_an_ entrepreneurial_ecosystem.pdf (accessed on 12 November 2020).

44. Feld, B. Startup Communities: Building an Entrepreneurial Ecosystem in Your City; Wiley: New York, NY, USA, 2012.

45. Foster, G.; Shimizu, C.; Ciesinski, S.; Davila, A.; Zahoor, H.S.; Jia, N.; Plunkett, S.; Pinelli, M.; Cunningham, J.; HiscockCroft, R.; et al. Entrepreneurial Ecosystems Around the Globe and Company Growth Dynamics; World Economic Forum: Geneva, Switzerland, 2013.

46. Vasin, S.M.; Gamidullaeva, L.A.; Wise, N.; Korolev, K.Y. Knowledge Exchange and the Trust Institution: A New Look at the Problem. J. Knowl. Econ. 2020, 11, 1026-1042. [CrossRef]

47. Aspen Network of Development Entrepreneurs. Available online: https:/ / www.andeglobal.org/ (accessed on 12 November 2020).

48. OC\&C Strategy Consultants. Available online: https:/ / www.occstrategy.com/en/ (accessed on 13 November 2020).

49. Ernst \& Young Global Limited. Available online: https://www.ey.com/en_gl (accessed on 12 November 2020).

50. Trabskaja, J.; Mets, T. Ecosystem as the Source of Entrepreneurial Opportunities. Foresight STI Gov. 2019, 13, 10-22. [CrossRef] 
51. Smilor, R.W.; Kozmetsky, G. Science and Technology Transfer in the United States. Handbuch Des Wissenschaftstransfers; Springer: Berlin/Heidelberg, Germany, 1990; pp. 811-819. [CrossRef]

52. Solesvik, M.; Westhead, P. Fostering of Entrepreneurship Competencies and Entrepreneurial Intentions in a Weak Ecosystem. Foresight STI Gov. 2019, 13, 60-68. [CrossRef]

53. Sala, S.; Ciuffo, B.; Nijkamp, P. A Systemic Framework for Sustainability Assessment. Ecol. Econ. 2015, 119, 314-325. [CrossRef]

54. Di Cesare, S.; Cartone, A.; Petti, L. A New Scheme for the Evaluation of Socio-Economic Performance of Organizations: A WellBeing Indicator Approach. In Perspectives on Social LCA; Springer: Cham, Switzerland, 2020; pp. 25-34.

55. Gamidullaeva, L.A.; Vasin, S.M.; Wise, N. Increasing small- and medium-enterprise contribution to local and regional economic growth by assessing the institutional environment. J. Small Bus. Enterp. Dev. 2020, 27, 259-280. [CrossRef]

56. Fuentelsaz, L.; Maícas, J.P.; Mata, P. Institutional Dynamism in Entrepreneurial Ecosystems. In Entrepreneurial Ecosystems: Place-Based Transformations and Transitions; O'Connor, A., Stam, E., Sussan, F., Audretsch, D.B., Eds.; Springer: Cham, Switzerland, 2018; pp. 45-65.

57. Harrington, K. Entrepreneurial Ecosystem Momentum and Maturity the Important Role of Entrepreneur Development Organizations and Their Activities, 1 September 2017; Kauffman Foundation, Kansas, KS, USA. Available online: https://www. kauffman.org/wp-content/uploads/2019/12/Entrepreneurial_Ecosystem_Momentum_and_Maturity_2017.pdf (accessed on 14 October 2020).

58. Verkhovskaya, O.R.; Bogatyreva, K.A.; Dorokhina, M.V.; Knatko, D.M.; Shmeleva, E.V. National Report "Global Entrepreneurship Monitor. Russia 2018/2019". Available online: www.gsom.spbu.ru (accessed on 14 November 2020).

59. International Standard for Sustainable Development in Communities ISO/DIS37101 and the Russian Standard GOST R 54598.12011. Available online: http:/ / docs.cntd.ru/document/1200089041 (accessed on 12 November 2020).

60. Local Entrepreneurship Ecosystems and Emerging Industries: Case Study of Małopolskie, Poland; OECD Local Economic and Employment Development (LEED) Working Papers. Final Report; OECD: Paris, France, 2019.

61. Rating of Sustainable Development of Cities in the Russian Federation. Available online: https://www.agencysgm.com/projects/ sostavlenie-reytinga-gorodov-rossii-v-oblasti-ustoychivogo-razvitiya/ (accessed on 12 November 2020).

62. Eurostat. Available online: https:/ / ec.europa.eu/eurostat/web/sdi/indicators (accessed on 14 November 2020).

63. Sustainable Urban Development in Poland: National Urban Policy in the Context of the 2030 Agenda's Goal 11 and the New Urban Agenda. 2019. Available online: https:/ / www.funduszeeuropejskie.gov.pl/media/72570/raport_en_final.pdf (accessed on 15 November 2020).

64. Volkmann, C.; Fichter, K.; Klofsten, M.; Audretsch, D.B. Sustainable entrepreneurial ecosystems: An emerging field of research. Small Bus. Econ. 2019. [CrossRef]

65. Bishop, P. Knowledge, diversity and entrepreneurship: A spatial analysis of new firm formation in Great Britain. Entrep. Reg. Dev. 2012, 24, 641-660. [CrossRef]

66. Guo, Q.; He, C.; Li, D. Entrepreneurship in China: The role of localisation and urbanisation economies. Urban Stud. 2016, 53, 2584-2606. [CrossRef]

67. Tavassoli, S.; Jienwatcharamongkhol, V. Survival of entrepreneurial firms: The role of agglomeration externalities. Entrep. Reg. Dev. 2016, 28, 746-767. [CrossRef]

68. Frenken, K.; Van Oort, F.; Verburg, T. Related variety, unrelated variety and regional economic growth. Reg. Stud. 2007, 41, 685-697. [CrossRef]

69. Yun, J.J.; Zhao, X.; Jung, K.; Yigitcanlar, T. The Culture for Open Innovation Dynamics. Sustainability 2020, 12, 5076. [CrossRef]

70. Gamidullaeva, L. Neo-institutional Approach for Regional Economic Development: The Impact of Sociocultural Determinants. Int. J. Econ. Bus. Adm. 2019, 7, 12-25. [CrossRef]

71. Belussi, F.; Sammarra, A.; Sedita, S. Learning at the boundaries in an "Open Regional Innovation System": A focus on firms' innovation strategies in the Emilia Romagna life science industry. Res. Policy 2010, 39, 710-721. [CrossRef]

72. Zeng, D.; Hu, J.; Ouyang, T. Managing innovation paradox in the sustainable innovation ecosystem: A case study of ambidextrous capability in a focal firm. Sustainability 2017, 9, 2091. [CrossRef]

73. Yun, J.J.; Zhao, X.; Yigitcanlar, T.; Lee, D.; Ahn, H. Architectural Design and Open Innovation Symbiosis: Insights from Research Campuses, Manufacturing Systems, and Innovation Districts. Sustainability 2018, 10, 4495. [CrossRef]

74. Cooke, P. Regional knowledge capabilities and open innovation: Regional innovation systems and clusters in the asymmetric knowledge economy. In Clusters, Networks E Innovation; Breschi, S., Malerba, F., Eds.; Oxford University Press: Oxford, UK, 2005.

75. Ivanov, V.V. Global Humanitarian and Technological Revolution: Preconditions and Prospects. Innovations 2017, 6, 11-16. Available online: https:/ / cyberleninka.ru/article/n/globalnaya-gumanitarno-tehnologicheskaya-revolyutsiya-predposylki-iperspektivy (accessed on 10 December 2020).

76. LeSage, J.P. What Regional Scientists Need to Know About Spatial Econometrics. 2014. Available online: https://ssrn.com/ abstract $=2420725$ (accessed on 15 November 2020). 